\title{
THE ARGUMENTS IN THE SABOTEUR TRIAL
}

\section{F. Granville Munson $\dagger$}

The trial of eight saboteurs by nilitary commission, held in Washington, in July and August, last, raised a number of questions of great moment and of universal interest. As a member of the prosecution staff who took an unimportant part in that trial, the writer was privileged to hear the discussions of these questions at first-hand, both before the commission and in the Supreme Court of the United States. The trial, as is well known, was held in camera and those who attended are under a pledge not to disclose the happenings in the courtroom. Hence this article is confined to those matters which are of public record, as shown in released statements and documents, and in counsels' briefs and arguments in the Supreme Court.

An effort is made in this article to suggest some of the principal arguments advanced on each side but it should be kept in mind that any comment thereon is made in advance of the opinion of the Supreme Court whose judgment may be found to rest on quite other grounds.

On July 7, 1942, the President appointed a military commission of seven general officers, "to try for offenses against the Law of War and the Articles of War", eight persons named in the order of appointment. These were the eight men who, in groups of four each, had landed on the coast of Long Island and of Florida, respectively. The preamble of this order gave as the basis of the President's authority his status as Commander-in-Chief of the Army and Navy and the authority vested in him by the Constitution and the statutes, more particularly the $3^{8 \text { th }}$ Article of War. ${ }^{1}$ The order further contained the following paragraph:

"The Commission shall have power to and shall, as occasion requires, make such rules for the conduct of the proceedings, consistent with the powers of Military Commissions under the Articles of War, as it shall deem necessary for a full and fair trial of the matters before it. Such evidence shall be admitted as would, in the opinion of the President of the Commission, have probative value to a reasonable man. The concurrence of at least two-thirds of the Members of the Commission present shall be necessary for a conviction or sentence. The record of the trial including any judgment or sentence shall be transmitted directly to me for my action thereon." 2

† B. S., 1903, University of Pennsylvania; LL. B., I906, Harvard University; Professor of Afilitary Law, Gcorgetown University; Colonel in the Judge Advocate Gencral's Department of the Regular Army.

I. 41 STAT. 794 (1920), 10 U. S. C. A. \$1509 (1927).

2. 7 FF. REG. 5103 (July 7, I942). 
The authorization thus given departed from the rules laid down for courts-martial in a number of important particulars. A courtmartial has no authority to make rules for the conduct of its proceedings. Its procedure is rather rigidly prescribed in the Manual for Courts-Martial (1928) which, by Executive order of November 29, 1927, is prescribed for the government of all concerned. The rule of evidence prescribed was entirely unlike the rule of evidence laid down

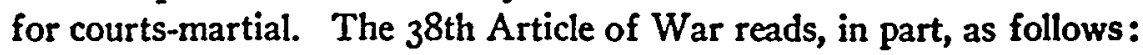

"The President may, by regulations, which he may modify from time to time, prescribe the procedure, including modes of proof, in cases before courts-martial, courts of inquiry, military commissions, and other military tribunals, which regulations shall insofar as he shall deem practicable, apply the rules of evidence generally recognized in the trial of criminal cases in the district courts of the United States: Provided, That nothing contrary to or inconsistent with these articles shall be so prescribed ...".?

A general court-martial, besides being governed by the 38 th Article of War, must have as one of its members a "law member"-an innovation introduced into the Articles by the revision of 1920. The law member (an officer of the Judge Advocate General's Department, if available) rules on interlocutory questions affecting the admissibility of evidence during the trial without reference to the other members." No law member was provided for on the military commission, although, as a matter of fact, a former Judge Advocate General of the Army was one of the members but given no authority to control the rulings of the president of the commission, a layman. A charge involving a death penalty before a general court-martial requires, for both conviction and sentence, the concurrence of all the members present at the time the vote is taken. At the conclusion of the trial, the findings and sentence of a general court-martial in capital cases must be laid before the board of review, a statutory board of three officers in the Judge Advocate General's Office and subsequently before The Judge Advocate General and if these two authorities disagree their respective opinions are transmitted to the Secretary of War, for the action of the President, the procedure being elaborately set forth in Article of War $50 \% 2 .^{\circ}$ The record of trial of the military commission was not given this review nor was any formal review by an authority subordinate to the President provided for. In several important particulars, there-

3. 4r STAT. 794 (1920), 10 U. S. C. A.ं. \& 1509 (r927). (1927).

4. Articles of War 8 and 3T, 4I STAT. 788, 793 (1920), 10 U. S. C. A. $\$ \$ 1479,1502$

5. Article of War 43, 4I Stat. 795 (1920), 10 U. S. C. A. \$ I5I4 (1927).

6. 41 Stat. 799 (1920), 10 U. S. C. A. $\$ 1522$ (1927). 
fore, the rules laid down for the guidance of this military commission were at variance with the statutory provisions for general courtsmartial.

Not only were departures from court-martial procedure prescribed by the appointing authority but the commission itself departed from these rules, two of such variances being the basis of objections made in the Supreme Court. The 18th Article of War, ${ }^{7}$ permits one peremptory challenge to each side in a general court-martial. The commission refused to allow any peremptory challenge. The rule laid down in Section II4 (c) of the Manual for Courts-Martial-which, of course, is nothing but the common law rule-that the statements of a conspirator made after the common design is accomplished or abandoned are not admissible against the others, except statements in furtherance of an escape, was not applied. And confessions made by each of the eight defendants when they were in custody were admitted against his seven fellows, not only on the charge of conspiracy, but on all the other charges.

It therefore became necessary, if the findings and sentence of the commission were to be upheld, to sustain the proposition that a military commission may be constituted by the President which could act independently of certain-perhaps all-the rules laid down for courtsmartial. This proposition naturally led to a discussion of the nature of military commissions and their points of likeness to and dissimilarity from courts-martial.

The origin of the military commission and its part in our history is well described by Colonel Winthrop. ${ }^{8}$ The occasion for the military commission, as he points out, arises principally from the fact that the jurisdiction of courts-martial proper is restricted by statute almost exclusively to members of the military forces and to certain specific offenses defined in a written code. For criminal acts peculiar to time of war or for acts of those not entitled to claim the benefits of the Articles of War, a different kind of tribunal is required and this is the body which we designate as a "military commission". It differs, too, from a court-martial in that it is more summary in its action, the extent of its powers is not defined by law, and it is not considered bound by the precise rules of procedure applicable to a court-martial. Winthrop refers to three classes of offenses cognizable by military commissions ${ }^{*}$ of which we are concerned here with only one-violations of the law and usages of war cognizable by military tribunals only. The law of

7. 41 Stat. 790 (1920), 1o U. S. C. A. \$ 1489 (1927).

8. Winthrop, Military LAW aNd Precedents (2d ed. reprint 1920) $83 t$ ef seg. WINTHROP, first published in 1886 , remains the only scientific treatise on our military law extant-an inviting field for a military writer.

9. Id. at 839 . 
war is not to be found in any statute or series of statutes. It was referred to, not inaccurately, in Ex parte Vallandigham," as the "common law of war" and, like the common law, does not consist of a formal written code but of rules derived from international law, acts and orders of the military power, the pronouncements of recognized authorities, such as Grotius, Vattel and Lieber, and international agreements embodied in such form as the Hague Conventions, and the like.11

When we come, therefore, to consider the extent of the jurisdiction and powers of a military commission, we are concerned with a tribunal whose limitations are not expressly defined in a field not sharply delimited. The strict constructionist may argue (and, in fact, that was the position taken before the Supreme Court by the defense) that there is no power to create a military commission and no right to confer power and authority upon it save as an act of Congress may permit. As there is no common law of the United States so, they argued, there is no common law of war. We must, in each case, refer to Congress for our authority.

For this position, the defense naturally turned to the inquiry of Justice Davis, speaking for the majority in Ex parte Milligan, ${ }^{12}$ when he asked:

". - from what source did the military commission that tried him derive their authority? Certainly no part of the judicial power of this country was conferred on them; because the Constitution expressly vests it 'in one Supreme Court and such inferior courts as the Congress may from time to time ordain and establish', and it is not pretended that the commission was a court ordained and established by Congress. They cannot justify on the mandate of the President; because he is controlled by law, and has his appropriate sphere of duty, which is to execute, not to make, the laws; and there is no unwritten criminal code to which resort can be had as a source of jurisdiction."

And likewise the minority used language which was relied on by the defense where, speaking through Chief Justice Chase, it declared:

"that there is no law for the government of the citizens, the armies or the navy of the United States, within American jurisdiction, which is not contained in or derived from the Constitution." 13 and again-

"We agree in the proposition that no department of the Government of the United States-neither President, nor Congress, nor the courts-possesses any power not given by the Constitution." 14

10. I Wall. 243,249 (U. S. 1863).

II. WINTHROP, op. cit. supra note 8, at 17, 41, 42, 773 et seq.

12. 4 Wall. 2, 121 (U. S. 1866).

13. Id. at I4I.

14. Id. at 136,137 . 
The answer of the Government to these contentions was based on two principal grounds. In the first place, it was said that invading enemies have no right to claim constitutional guarantees under the law of war. These privileges are for "subjects". ${ }^{18}$ Whoever may be meant by "subjects", certainly the term is not broad enough to cover enemies who come to our shores as invaders. Neither the majority nor the minority could have had such persons in mind in Ex parte Milligan. It is true that sometimes the privilege of our courts has been allowed enemy aliens who are lawful residents of our country but their case is obviously distinguishable and, in any event, it is but a license or privilege which can be terminated at any time. ${ }^{16}$ In.January of the present year, the Supreme Court denied the right of the Italian Government to sue out a writ of prohibition or mandamus to secure possession of a ship which had been seized as the property of an Italian national. ${ }^{18}$ The Court relied on Sections 2 and 7 (b) of the Trading with the Enemy Act, ${ }^{18}$ and, in a per curiam opinion, said:

"This provision was inserted in the Act in the light of the principle, recognized by Congress and by this Court, that war suspends the right of enemy plaintiffs to prosecute actions in our courts. - . In view of the statute and the opinions in the cases cited, the application will not be entertained. . . ." 10

In the argument, the Chicf Justice, referring to this case, stated that while he assumed the Italian Government could not bring suit to quiet title in our courts, if it had been in possession and its prerogative were being assailed, that might be heard as a defense.

Access to the courts by alien enemies as a matter of privilege, but not of right, was early recognized, the Attorney General argued, by the Act of July 6, 1798 , still on the statute books, ${ }^{20}$ wherein the President is authorized "to direct the conduct to be observed, on the part of the United States" towards them, "the manner and degree of the restraint to which they shall be subject ... and to establish any other regulations which are found necessary in the premises and for the public safety".21 Denial of access need not be limited to alien enemies-it can be extended to nationals who are, in fact, enemies. Even conceding that one of the saboteurs had never lost his citizenship, by actively

15. 9 Halsbliry's Iaws of England (2d ed. 193I) 710, f 1212.

16. Rex v. Supt. Vine St. Police Station [1916] I K. B. 268, 279; Schaffenius Y. Goldberg [1916] I K. B. 284; Ex parte Graber, 247 Fed. 882 (N. D. Ala. 1918); Alinotto v. Bradley, 252 Fed. 600 (N. D. Ill. 1918).

17. Ex parte Colonna, 314 U. S. 510 (1942).

18. 40 STAT. 41 I, 416 (I917), 50 U. S. C. A. app, $\$ \S 2,7$ (b) (1928).

19. 314 U. S. 510,511 (1942).

20. 40 Stat. 531 (I798), 50 U. S. C. A. \$2I (I928).

21. DeLacey v. U. S., 249 Fed. 625 (C. C. A. gth, 1918); Brown v. U. S, 8 Cranch ino (U. S. 1814); Miller v. U. S, II liall. $26 \delta^{\prime}$ (U. S. 18;0); Juargua Iron Co. v. U. S, 212 U. S. 297 (1908). 
aiding an enemy nation and undertaking belligerent actions on its behalf, he became impressed with the character of an enemy and equally, with alien enemies, could be denied access to the courts. ${ }^{22}$

The second ground on which reliance was placed was the President's Proclamation of July 7, 1942, which is of such importance as to warrant quoting the substantive portion, in full:

"Whereas the safety of the United States demands that all enemies who have entered upon the territory of the United States as part of an invasion or predatory incursion, or who have entered in order to commit sabotage, espionage or other hostile or warlike acts, should be promptly tried in accordance with the law of war;

Now, Therefore, I, Franklin D. Roosevelt, President of the United States of America and Commander in Chief of the Army and Navy of the United States, by virtue of the authority vested in me by the Constitution and the statutes of the United States, do hereby proclaim that all persons who are subjects, citizens or residents of any nation at war with the United States or who give obedience to or act under the direction of any such nation, and who during time of war enter or attempt to enter the United States or any territory or possession thereof, through coastal or boundary defenses, and are charged with committing or attempting or preparing to commit sabotage, espionage, hostile or warlike acts, or violations of the law of war, shall be subject to the law of war and to the jurisdiction of military tribunals; and that such persons shall not be privileged to seek any remedy or maintain any proceeding, directly or indirectly, or to have any such remedy or proceeding sought on their behalf, in the courts of the United States, or: of its states, territories, and possessions, except under such regulations as the Attorney General, with the approval of the Secretary of War, may from time to time prescribe." 28

The President, the Attorney General argued, being Commanderin-Chief of the armed forces may, as an act of war, deny access to the courts. But, in so doing he is not acting outside the Constitution for that instrument, in creating him Commander-in-Chief, did not purport to limit and define his powers as such. Consequently, for such limitation and definition, we must refer to those powers possessed by the head of military forces under the law of war. ${ }^{24}$

22. Hall, International. Laiv (ig09) 490-497; 2 Oppengeias, Interkational Law (1940) 216-218; The Venus, 8 Cranci 253, 278 (U. S. I814).

23. 7 FED. REG. 5 IOI (July 7, 1942).

24. The defense argued that there was "a serious question as to whether there was any such offense as the violation of the law of war." I suppose the theory was that as Congress was specifically given power in Article 1 , Section 8 , of the Constitution to define offenses against the law of nations, in the absence of a statute defining it, there could be no such offense. 
The extent of the President's war powers is a subject, I take it, which will always be a fruitful source of contention and ground for endless legal argument. It is not likely that any opinion which the Supreme Court may render in this case will be regarded as final and conclusive by those who do not happen to agree with the conclusions which the Court may reach, for it will be too easy to consider the opinion to have been based on the very novel features of the case. Inter arma leges silent will never, fortunately, be accepted as literally true to its fullest extent and one has but to recall the outburst which greeted President Lincoln's suspension of the privilege of the writ of habeas corpus to realize how jealously our people protest against anything which they think savors of dictatorship. ${ }^{25}$ But must the President, as Commander-in-Chief of the armed forces, be limited to repelling the enemy solely by physical force? If he may close the ports of the United States to nationals acting hostilely to the United States, as was held was his right in the Prize Cases, ${ }^{28}$ why may he not also close the courts to alien enemies or to nationals acting with such enemies? The latter action is as much an act of war as the former: Why may he not wage "total war" in a very literal sense? Mr. Justice Holmes summed up the position taken by the Government in this case, in Moyer $v$. Peabody, ${ }^{27}$ where, in a case in which the court refused to inquire into the necessity for a declaration of martial law by the Governor of Colorado, he said, in his usual clear and succinct way:

"When it comes to a decision by the head of the State, upon a matter involving its life, the ordinary rights of individuals must yield to what he deems the necessities of the moment. Public danger warrants the substitution of executive process for judicial process."

It may be conceded that possibly there could be a conflict. between the acts of the President as Commander-in-Chief under his war powers and the statutes of Congress covering the same ground. The question how far, if at all, Congress may limit the President's war powers will not, in our opinion, be decided by the saboteur case because we contend that in that case the President's acts as Commander-in-Chief were in conformity with his constitutional and statutory powers. But the Attorney General made clear what position he would have taken had he conceived such a conflict. "I am not at all sure", he said, "that the Government in that case (i.e. the Milligan case) could not have argued with some force that in time of war an act which prevented the Presi-

25. See 3 Rhiodes, History of the United States (I928) 325 et seq.; 4 Id. 229. 26. 2 Black 635 (U. S. 1862 ).

.27. 212 U. S. 78,85 (1908). See also Sterling v. Constantin, 287 U. S. 378 (1932). 
dent of the United States and the Commander-in-Chief as a soldier and as a Commander from dealing with spies in his own way would have been unconstitutional".

Presumably nothing concerning the forthcoming opinion of the Supreme Court will be of greater interest to the profession than the effect it will have on Ex parte Milligan. ${ }^{28}$ Naturally, this landmark, which has stood on the books for seventy-six years, was in the mind of all counsel. (There was unconscious humor in a telegram, received just before the argument, asking if we had heard of it). Briefly stating its well-known facts, Milligan was a citizen of Indiana who had lived there some twenty years when, in 1863 , he was arrested at his home by the military authorities and brought to trial before a military commission for conspiring by divers means to overthrow the Government, such as joining a seditious secret society, seizing munitions of war, liberating prisoners of war, resisting the draft, communicating with the eneny, ctc. He was found guilty and sentenced to be hanged, but the findings and sentence were not confirmed by President Lincoln, but by his successor, President Johnson. A divided circuit court brought the case before the Supreme Court where it was held that a military commission was without authority to try a civilian not connected with the armed forces so long as the courts were open, that the courts could never legally be closed except where martial law had been declared, basici on an actual invasion rendering the courts incapable of performing their duties, and Indiana had not been invaded in that sense. The roint really decided was that the Act of March 3, $1863^{29}$ requiring the reporting of Milligan's name to the civil court and his subsequent indictment by a grand jury had not been complied with. But it was a dictum-accepting the Court's position that legislation could prohibit a military trial-that has caused so much argument. The majority, taking the view that Congress, under the conditions stated, had prohibited a trial by military commission, went on to state that even if it had passed a statute permitting such a trial, it would have been unconstitutional. A minority of four, speaking through Chief Justice Chase, rigorously denied this position. Both majority and minority, therefore, while agreeing in the result, reached that result by different routes- the minority said that Congress had not authorized the military trial, the majority said Congress could not authorize it.

In the Government's argument in the Supreme Court, the Attorney General referred to Ex parte Milligan in a way that, on first impression, might seem inconsistent. At one place in his argument, he made the statement that the Court could satisfy all the requirements of the case 
"without touching a hair of the Milligan case" but, at two other places, he asked the Court to overrule it as "very bad law" and as having a harmful effect not only on the courts but on the army. The inconsistency is more apparent than real for the difficulty is in determining precisely what the Milligan case stands for in the minds of judges, today. The writer's opinion is that the facts of the saboteur case are so different from those in the Milligan case that he who runs may read. Milligan was "not a resident of one of the rebellious states, or a prisoner of war;" ${ }^{30}$ he did not break through our lines as an armed and uniformed member of a hostile invading band; he was not an alien enemy or impressed with an enemy character; he was not equipped with false documents to disguise his enemy character; he had no official connection with the Confederate Government; he had lived at his domicile twenty years and had not been apprehended after a surreptitious entry into Indiana; and certainly if Indiana was not a "theatre of operations" in 1863 , it was in no wise comparable to the Atlantic seaboard in 1942. It seems that a "theatre of operations" is a fact and not a theory; and although it was proved conclusively enough that military and naval orders put the places where these saboteurs landed within the zone of active military operations, that proof would scem quite unnecessary. When submarines are lurking off the coast and sinking ships within sight of summer cottagers (as at Virginia Beach), patrols and blackouts are found along our entire seaboard and wreckage froni torpedocd vessels is washed ashore, we have a "theatre of operations" in a very real sense. An area of the war, as one of the justices suggested, may be created by the act of the enemy, as well as by our own act. To hold that Milligan, the citizen, could not be denied access to the civil courts is a far cry from asserting that these eight enemy saboteurs had the same right. Even in the first World War it was clearly recognized how changed are the conditions of modern warfare. In United States $v$. McDonald ${ }^{31}$ the District Court, in holding that a German spy who was operating about the port of New York was sufficiently within the theatre of war to justify trial by naval court-martial, said:

"The term, 'theatre of war', as used in the Milligan case,apparently was intended to mean the territory of conflict. With the progress made in obtaining ways and means for devastation and destruction, the territory of the United States was certainly within the field of active operations. . . . One of the lessons taught by this war is that the ocean is no longer a barrier for

30. Ex parte Milligan, 4 Wall. 2, 118 (1866). 705 (1920).

31. 265 Fed. 754 (E. D. N. Y. 1920), appeal dismissed on stipulation, 256 U. S. 
safety or an insurance against America's being involved in European wars. She cannot now become an asylum of safety for spies." 32

But it cannot be denied that the Milligan case is assumed to stand for the principle that where civil courts are open and accessible under such circumstances as prevailed in that case, there can be no trial by military commission, and that is a principle which I think can very properly be characterized as "very bad law". In the first place, it is an unrealistic test. On the days on which the saboteurs landed in New York and Florida, respectively, the civil courts were open and functioning. In order to try them by military commission, then, was it necessary to close the civil courts and declare martial law? "The doctrine of the majority in Ex parte Milligan", said Professor Fairman, in a recent article, "does not go far enough to meet the conditions of modern war".32 And again, as the same author writes, in his book, Martial Rule, "t4 "the necessity for martial rule arises rather from the proximity of a danger than from the fact that the courts are closed." Martial law, as Chief Justice Chase pointed out in the Milligan case, ${ }^{38}$ is invoked where the ordinary law no longer adequately secures public safety and private rights. The law of war, on the other hand, not being concerned with crimes as such but with acts interfering with the conduct of the war, covers another field from that with which the civil courts are concerned. For example, spying is not, technically, a crime but an offense against the law of war. "A spy, who, after rejoining the army to which he belongs, is subsequently captured by the enemy . . . incurs no responsibility for his previous acts of espionage." 8 Likewise he must be tried and convicted during the existence of the war. ${ }^{37}$. The escape of a criminal or the end of a war is certainly no defense to a charge of crime as such.

The contention of the defense was that once Congress made an act a criminal offense, the same act could not constitute an offense against the law of war and, ipso facto, the military commission lost jurisdiction. There is the offense of spying, punishable only by a military tribunal under the 82nd Article of War, and there is a civil offense of espionage. ${ }^{38}$ "Here", argued the defense, "Congress has legislated

32. 265 Fed. $754,763-764$ (E. D. N. Y. 1920).

33. Fairman, The Law of Martial Rule and the National Emergency (1942) 55 HARV. L. REv. 1254. This is an excellent article by one now on duty as a judge advocate in the Army.

34. Fatranan, Martial Rurx (1930) 147.

35. Ex parte Milligan, 4 Wall. 2, 141 (U. S. 1866).

36. ANNEX TO HAGUE CoNiENTION, art. 31, 36 STAT. 2304 770.

37. In re Martin, 45 Barb. 142 (N. Y. 1863); Wrsturop, op. cil. supra note 8, at

38. 40 Stat. 217 (1917), 50 U. S. C. A. \$\$ 31, 32 (1928). 
on the subject, on the very thing those men have done, at the most, and the difference in the case of these petitioners is a difference between a maximum of thirty years and a mandatory death sentence. . . . Congress thought thirty years was enough." The fallacy of this argument seems to be demonstrated by such a case as U.S. v. Greence et al., ${ }^{39}$ where the two civilian conspirators were tricd by a district court, the military conspirator having already been tried by a general courtmartial. The contention of the military offender that he was entitled to a civil trial has never been successfully maintained before courts or committees of Congress, although insisted upon down to the present day. ${ }^{10}$ One cannot select his own tribunal for trial nor insist on trial by the tribunal which can impose the lighter penalty.

The case of Pablo Waberski in the first World War was cited as authority against the position taken by the Government. It must be frankly conceded that Attorney General Gregory's ruling ${ }^{11}$ was flatly contra to the position taken by his successor in this argument. Waberski was a German national who had crossed into our territory from Mexico at least three times within twenty-four hours, and was arrested in the town of Nogales, about a mile distant from an encampment. Attorney General Gregory made this statement:

"However, if there were no Milligan case to furnish us with an authoritative precedent, the provisions of the Constitution. would themselves plainly bring us to the same conclusions as those set forth in the opinion of the court in that case, namely, that in this country, military tribunals, whether courts-martial or military commissions, cannot constitutionally be granted jurisdiction to try persons charged with acts or offenses çommitted outside of the field of military operations or territory under martial law or other peculiarly military territory, except members of the military or naval forces or those immediately attached to the forces such as camp followers." 42

Were this not the case, said $\Lambda$ ttorney General Gregory, any person charged with espionage could be tried by military court, contrary to the Constitution, and any other conclusion would be tantamount to applying martial law without justification for martial law existing. But the authority of that opinion, involving, it is subnitted, the fallacies already pointed out, is practically overthrown by a later opinion which, until the argument in the Supreme Court, had not been released for publication.

39. 146 Fed. 803 (S. D. Ga. 1906).

40. See Carter v. Woodring, Sec'y of War, 92 F. (2d) 544 (C. C. A. D. C. 1937). The writer has represented the IVar Department, in recent years, where the military conviction in this famous case, so often before the courts, has been attacked as invalid.

41. 31 OPS. ATt'y. GeN. 356 (1918).

42. Id. at $36 \mathrm{r}$. 
On December 24, 1919, Attorney General Paliner pointed out such crrors of fact in the Gregory opinion as that Waberski was an alien enemy, and not a Russian national (as his predecessor had assumed) and held flatly that Waberski was subject to trial as a spy under the 8and Article of War. In reaching this contrary result, he referred neither to martial law nor to whether the courts were open.

Counsel for the petitioners with great ability advanced several interesting arguments which merit consideration, even if one feels constrained to take a contrary view. The Fifth Amendment excepts from presentment or indictment only those cases arising in the land or naval forces, or in the militia, when in actual service in time of war or public danger. While a "case", of course, may arise in those forces which does not involve a member of such forces, it was contended that unless the offenses alleged against the saboteurs, were connected with the land or naval forces, $i$. $e$., arose in the land or naval forces, they were only subject to trial by civil court. What, then, is a case "arising in the land or naval forces"? Counsel devoted a good part of their argument to illustrating the difference. "Mere sabotage", they argued, "is not a military operation" and must be distinguished from destruction of property in military operations. Similarly, the military offense of spyin $\tilde{\boldsymbol{\xi}}$ is not to be confused with the civil offense of espionage. There are civil statutes to cover espionage and sabotage. ${ }^{43}$ If an enemy were gathering information from an industrial establishment, that would not be the military offense of spying, even if the plant were making guns, because it would not be a case arising in the land or naval forces, and hence merely the civil offense of espionage. One must look at something of a military nature and endeavor to get information thereby to be guilty of the military offense of spying. $\Lambda$ pparently, the argument is one of degree. It was even admitted that if the saboteurs had been able to land at an out-of-the-way place and bury tanks or planes in the darkness, that would have been "a preparatory stage and not a stage of actual combat." How far this distinction would be carried is illustrated by the following colloquy:

"Mr. Justice Frankfurter. If a German division marched on the Glenn Martin plant, that would be a zone of military oparations?

Colonel Royall: There is no doubt about that.

$\mathrm{Mr}$. Justice Frainkfurter. What kind of a distinction do you have in mind?

Colonel Royall. The distinction is one of military operations and industrial interference.

43. 40 Stat. 217 et seq., 533 et seq. (1917), 50 U. S. C. A. \$§3r-42, 101-106 (1928). 
Mr. Justice Frankfurter. May I suggest to you that that makes the distinction turn on the antiquity of the mode?

Colonel Royall. I can see that point of view; and that is the total war theory.

Mr. Justice Frankfurter. I.have not used those words.

Colonel Royall. No; you have not, sir. But the total war theory is that anything that affects the war effort is a part of the war. There has got to be some limit on that, or we have very few constitutional guarantees left when we go to war."

While we may agree that there has to be some limit on the total war theory, I think we would hardly draw it at the same place as counsel for the defendants. "Gentlemen of England, fire first", may have been the invitation of the polite Frenchmen at the Battle of Fontenoy, but even at that, the invitation was not so broad as to include an attack on the whole French nation.

The intimation of the defense that there is no such thing as an offense against the law of war which is not based on a statute of Congress has already been mentioned. The 15 th Article of War prescribes that the jurisdiction conferred by the Articles shall not be construed as depriving military commissions of concurrent jurisdiction over offenses "punishable by the law of war", without further defining these offenses. The defense, when pressed, maintained this position and went even farther-not only must the offense be defined by statute but it must constitute a case arising in the land or naval forces. The arguments advanced for this position have already been stated.

There was much argument of a technical nature on the general question of how far the Articles of War were binding on military commissions which limitations of space prevent discussing at any length. Seven Articles mention military commissions. ${ }^{44}$ No Article prescribes the mode of procedure of a military commission, the $15^{\text {th }}$, 8oth, 81st, and 82nd Articles being concerned only with the concurrent jurisdiction of military commissions and courts-martial. In my opinion, the strongest point made by the defense was its contention that the 38 th Article (set forth in full, above) adopts for military commissions the procedure, including modes of proof, which is prescribed for courtsmartial. Perhaps the most satisfactory answer is found in the argument that the correct meaning of A. W. 38 is that nothing contrary to or inconsistent with the Articles of War should be prescribed, so far as these Articles refer to courts-martial. There being no provisions in the Articles dealing with the procedure of military commissions, it may be said that the President is not restricted by the proviso as he is in

44. ARticles of WAR 15, 27, 38, 46, 80-82, 41 Stat. 790, 792, 794, 796, 804 (1920), 10 U. S. C. A. $\S \S 1.4 \$ 6,1498,1509,1517,1552-54$ (1927). 
the case of courts-martial. This point and the lengthy argument over the right of review by the board of review provided for by A. W. $502^{1} 2^{15}$ will perhaps not greatly interest the non-military lawyer.

Another point on which the opinion of the Court will be awaited is how far it accepted the mandate of the President that these defendants should not have access to the courts, either directly or indirectly. The per curiam memorandum read from the bench granted petitions for writs of certiorari, before judgment, to the United States Court of Appeals for the District of Columbia, pursuant to Title 28, Sections 347 and 348 , of the United States Code, referred to the fact that the questions raised in the cases had been thoroughly argued at the bar and that the court had reached its conclusions thereon, and then announced holdings that the charges preferred against the prisoners could properly be brought to trial before a military commission, that the commission was lawfully constituted and the petitioners in lawful custody and that they had not shown cause for being discharged by writ of habeas corpus. The motion for leave to file writs of habeas corpus was denied and the order of the District Court affirmed. Can a court go this far and yet assert it has not taken jurisdiction? This is not the least interesting question for which we must await the opinion of the Court.

45. 50 Stat. 72.4 (1937), 10 U. S. C. A. 81522 (Supp. 1941 ). 